\title{
Nitrogen and carbon isotope values of individual amino acids: a tool to study foraging ecology of penguins in the Southern Ocean
}

\author{
Anne Lorrain ${ }^{1, *}$, Brittany Graham ${ }^{2,3}$, Frédéric Ménard ${ }^{4}$, Brian Popp ${ }^{5}$, \\ Steven Bouillon ${ }^{6,7,8}$, Peter van Breugel ${ }^{6}$, Yves Cherel ${ }^{9}$
}

\author{
${ }^{1}$ IRD/LEMAR, Centre IRD de Brest, BP 70, 29280 Plouzané, France \\ ${ }^{2}$ Department of Oceanography, University of Hawaii, Honolulu, Hawaii 96822, USA \\ ${ }^{3}$ SINLAB, Canadian Rivers Institute, University of New Brunswick, Fredericton, New Brunswick E3B 5A3, Canada \\ ${ }^{4}$ IRD, UMR 212 EME, Centre de Recherche Halieutique (CRH), Avenue Jean Monnet, BP 171, 34203 Sète Cedex, France \\ ${ }^{5}$ Department of Geology and Geophysics, University of Hawaii, 1680 East-West Rd., Honolulu, Hawaii 96822, USA \\ ${ }^{6}$ Centre for Estuarine and Marine Ecology, Netherlands Institute of Ecology (NIOO-KNAW), PO Box 140, 4400 AC Yerseke, \\ The Netherlands \\ ${ }^{7}$ Dept. of Analytical and Environmental Chemistry, Vrije Universiteit Brussel, Pleinlaan 2, 1050 Brussels, Belgium \\ ${ }^{8}$ Dept. of Earth \& Environmental Sciences, Katholieke Universiteit Leuven, Kasteelpark Arenberg 20, 3001 Leuven, Belgium \\ ${ }^{9}$ CEBC, UPR 1934 du CNRS, BP 14, 79360 Villiers-en-Bois, France
}

\begin{abstract}
We determined the $\delta^{15} \mathrm{~N}$ and $\delta^{13} \mathrm{C}$ values of individual amino acids (AAs) isolated from chick blood of 4 penguin species that forage in different oceanic regions (from the subtropics of the Indian Ocean to Antarctica) to test if: (1) the $\delta^{15} \mathrm{~N}$ values of phenylalanine $\left(\delta^{15} \mathrm{~N}_{\text {phe }}\right)$ revealed different foraging areas among the species; (2) the difference between glutamic acid and phenylalanine $\delta^{15} \mathrm{~N}$ values $\left(\Delta \delta^{15} \mathrm{~N}_{\text {glu-phe }}\right)$ accurately predicted trophic levels; and (3) the $\delta^{13} \mathrm{C}$ value of AAs could resolve species foraging locations, similar to bulk $\delta^{13} \mathrm{C}$ values. The $\delta^{13} \mathrm{C}$ values of all AAs decreased with latitude, were positively correlated with bulk $\delta^{13} \mathrm{C}$ data, and, therefore, tracked the isotopic baseline. However, we were not able to discern additional ecological information from these $\delta^{13} \mathrm{C}$ values. In contrast, the $\delta^{15} \mathrm{~N}$ values of AAs distinguished the isotopic value of the nitrogen at the base of the food web from the trophic level of the consumer, providing new insight for the study of the trophic ecology of seabirds. The difference in the bulk $\delta^{15} \mathrm{~N}$ values of northern and southern rockhopper penguins Eudyptes chrysocome ssp. was due to both a difference in their foraging location (different $\delta^{15} \mathrm{~N}_{\text {phe }}$ ) and their trophic levels (different $\Delta \delta^{15} \mathrm{~N}_{\text {glu-phe) }}$ ). The $\delta^{15} \mathrm{~N}_{\text {phe }}$ values of king Aptenodytes patagonicus and Adélie penguins Pygoscelis adeliae were higher than those of rockhoppers, which could reflect a foraging on mesopelagic prey for king penguins and, in the highly productive Antarctic shelf waters, for Adelie penguins. The $\Delta \delta^{15} \mathrm{~N}_{\text {glu-phe }}$ accurately reflected the relative trophic level of penguins, but further work is required to determine the trophic enrichment factors for compound-specific isotope analysis.
\end{abstract}

KEY WORDS: $\delta^{15} \mathrm{~N} \cdot \delta^{13} \mathrm{C} \cdot$ Compound specific $\cdot$ Isotopic niche $\cdot$ Trophic level

Resale or republication not permitted without written consent of the publisher

\section{INTRODUCTION}

Determining dietary preference together with foraging habitat of marine predators can be challenging because of the extent of their pelagic environment and their long-distant movements. Traditionally, the diet of predators has been determined by stomach content, bulk stable isotopes, and fatty acid analyses (Hyslop 1980, Michener \& Schell 1994, Iverson et al. 2004). Foraging habitat can be investigated with tagging technologies (Wienecke et al. 2000, Charrassin \& Bost 2001, Bost et al. 1997) or by linking a predator's stable isotope compositions with the isotope values of the local environment (Lee et al. 2005, Cherel et al. 2006, 
2007, Wallace et al. 2006). The $\delta^{13} \mathrm{C}$ and $\delta^{15} \mathrm{~N}$ values of phytoplankton at the base of marine food webs can vary greatly due to different factors including phytoplankton community composition, nutrient utilization, differences in nutrient sources (e.g. denitrification vs. $\mathrm{N}_{2}$ fixation) and the subsequent biological transformations of these nutrients (Altabet 2001, Sigman \& Casciotti 2001, Karsh et al. 2003, Tamelander et al. 2009). The resulting spatial gradients in phytoplankton or zooplankton $\delta^{13} \mathrm{C}$ and $\delta^{15} \mathrm{~N}$ values (e.g. inshore/offshore, pelagic/benthic, latitudinal) have been shown to propagate up to consumers and have served as proxy values for the foraging habitat of consumers (Best \& Schell 1996). For example, bulk $\delta^{13} \mathrm{C}$ values have been used to determine the foraging habitats of cetaceans and seabirds (Best \& Schell 1996, Cherel et al. 2006, 2007, Quillfeldt et al. 2005), and bulk $\delta^{15} \mathrm{~N}$ values have been used to delineate temporal changes in the foraging regions of marine mammals (e.g. Burton \& Koch 1999, Newsome et al. 2007). However, only a few of these studies directly compare the baseline and predator isotope values (Lee et al. 2005). Instead, the spatial variation in the isotopic baseline is inferred by knowledge of the local oceanography and from previous studies that characterized variations in the isotopic baseline from isotopic analyses of, e.g., particulate organic matter (POM) or zooplankton (Cherel \& Hobson 2007, Ménard et al. 2007). A spatial knowledge of baseline isotope variations and an understanding of the physiology and ecology of the marine predator are required for interpretation of the bulk $\delta^{13} \mathrm{C}$ and $\delta^{15} \mathrm{~N}$ values of predators. However, characterizing the isotopic baseline at the scale of ocean basins is logistically challenging (Jennings \& Warr 2003) and speculative for historical periods when archived specimens are examined.

Recent evidence suggests that compound-specific isotopic analyses (CSIA) of individual amino acids (AAs) isolated from marine consumers could distinguish the isotopic value of the nitrogen at the base of the food web from the trophic level (TL) of the consumer (McClelland \& Montoya 2002, Chikaraishi et al. 2007, Popp et al. 2007, Hannides et al. 2009). Results of the laboratory experiments by McClelland \& Montoya (2002) showed that the $\delta^{15} \mathrm{~N}$ value of 'trophic' AAs (e.g. glutamic acid) can be enriched by as much as $\sim 7 \%$ in the marine rotifer Brachionus plicatilis relative to the $\delta^{15} \mathrm{~N}$ value in the alga Tetraselmis suecica, whereas other 'source' AAs (e.g. phenylalanine) are little affected by trophic status and retain the $\delta^{15} \mathrm{~N}$ values of the phytoplankton or cyanobacteria at the base of this food web. The implication of these results are that both $\mathrm{TL}$ and the nitrogen isotopic baseline where predators foraged can be determined by analyzing only the $\delta^{15} \mathrm{~N}$ values of individual AAs isolated from a predator's tissue (see also Schmidt et al. 2003, Popp et al. 2007, Hannides et al. 2009). However, to date, CSIA of individual AAs has mainly been applied to low TLs (McClelland \& Montoya 2002, Schmidt et al. 2004, Chikaraishi et al. 2007, Hannides et al. 2009), with only one vertebrate predator study (tuna; Popp et al. 2007), and no work has yet been conducted on birds or mammals. Carbon CSIA on individual AAs has mainly focused on the metabolic pathways of animals (e.g. O'Brien et al. 2005), but the results of Fantle et al. (1999) on blue crabs suggested that the $\delta^{13} \mathrm{C}$ values of individual AAs (both essential and non-essential AAs) could complement bulk isotopic results to decipher a consumer's food sources.

In the present paper, we analyzed the $\delta^{15} \mathrm{~N}$ and $\delta^{13} \mathrm{C}$ values of individual AAs isolated from chick blood of 4 Southern Ocean penguin species: northern rockhopper (NRP, Eudyptes chrysocome moseleyi), southern rockhopper (SRP, Eudyptes chrysocome chrysocome), king (KP, Aptenodytes patagonicus) and Adélie (AP, Pygoscelis adeliae) penguins. These Southern Ocean penguins could be ideal species to test the efficacy of AA $\delta^{15} \mathrm{~N}$ and $\delta^{13} \mathrm{C}$ analyses to determine the ecological niches of seabirds, as their food habits and foraging regions are diverse and well documented (details in Cherel \& Hobson 2007). Both bulk stable isotope and stomach content analyses showed different foraging strategies among these species (e.g. fish vs. crustaceans, see Table 1). Furthermore, their foraging habitats differ (see Table 1 and related references), and their breeding colonies are located at sites encompassing a large latitudinal range, from the subtropical Amsterdam Island north of the Subtropical Front, over the Crozet Islands in the Polar Frontal Zone to Adélie Island, Antarctica (Table 1). These regions exhibit different oceanographic characteristics (temperature, chlorophyll a concentrations, sea-ice extent) that could lead to spatial variations in the carbon and nitrogen isotopic compositions at the base of the food web (see Fig. 1; Altabet \& François 1994, Trull \& Armand 2001). In the southwest Indian Ocean, the $\delta^{13} \mathrm{C}$ and $\delta^{15} \mathrm{~N}$ values of POM show an abrupt decrease between 40 and $45^{\circ} \mathrm{S}$ (François et al. 1993, Altabet \& François 1994), leading to a north-south gradient across the subtropical frontal zone. This latitudinal gradient can, however, be complicated by inshore-offshore productivity gradients (Cherel \& Hobson 2007), the influence of blooms and nutrient utilization (Karsh et al. 2003, Tamelander et al. 2009), the mixing of water masses across the frontal zone, and the contribution of sea-ice phytoplankton to the food web (Hobson et al. 1995, Gibson et al. 1999, Norkko et al. 2007).

The present study is the first to analyze carbon and nitrogen isotopes of individual AAs in seabirds, and also the first to analyze AAs isolated from whole blood. 
It should be noted that adult penguins can segregate their diet from the food they feed their chicks (Cherel 2008). Our study is limited to the chicks' diet and the adults' foraging areas when they feed their chicks, but does not cover the adult's diet. Based on our current knowledge of this species, 3 predictions were tested:

1. NRP chicks have $\delta^{15} \mathrm{~N}$ values $2.4 \%$ higher than those of SRP chicks (Cherel \& Hobson 2007). We expect this bulk isotopic difference to be mainly due to isotopic baseline differences in the areas where penguins feed. NRP forage in the Subtropical Zone, where $\delta^{15} \mathrm{~N}$ values of POM are higher than in the Polar Frontal Zone (Altabet \& François 1994), where SRPs feed. Since phenylalanine is a source AA and should reflect the isotopic baseline, the $\delta^{15} \mathrm{~N}$ values of phenylalanine $\left(\delta^{15} \mathrm{~N}_{\text {phe }}\right)$ in the blood of NRP should be higher than those of SRP (Cherel \& Hobson 2007).

2. KP feed heavily upon fish compared to SRP, NRP and AP, which mainly eat crustaceans. Thus, KP should have the highest TL (Cherel et al. 2007, 2008); we, therefore, predict that KP will show the greatest difference between source and trophic AA $\delta^{15} \mathrm{~N}$ values.

3. High-latitude oceanic ecosystems (without considering onshore-offshore gradients) typically have much lower POM $\%{ }^{13} \mathrm{C}$ values than subtropical regions (François et al. 1993, Goericke \& Fry 1994) and reflect the $\delta^{13} \mathrm{C}$ values of phytoplankton (Popp et al. 1999). The bulk $\delta^{13} \mathrm{C}$ values of these penguins decreased with increasing latitude, which was attributed to the difference in the $\delta^{13} \mathrm{C}$ values of the baseline in their respective foraging areas (Cherel \& Hobson 2007). If some AAs provide information about the carbon source incorporated in food webs, the $\delta^{13} \mathrm{C}$ values of these AAs should also track spatial variations in the $\delta^{13} \mathrm{C}$ values and we expect the $\delta^{13} \mathrm{C}$ value of some specific AAs to decrease with increasing latitude, similar to the bulk $\delta^{13} \mathrm{C}$ values.

\section{MATERIALS AND METHODS}

Sample collection. A detailed description of breeding colony sites, collection methods and bulk isotope analyses for these penguin samples can be found in Cherel \& Hobson (2007) and in our Table 1. We present here only a brief description of the methods used to collect blood samples from penguin chicks. Four species of penguins were sampled from 3 different breeding areas during the austral summer 2001/2002 (Fig. 1). NRP and SRP chicks were collected from Amsterdam Island and the Crozet Islands, respectively. KP chicks were also collected from the Crozet Islands, while AP chicks were collected at Pointe Géologie Archipelago in Adélie Land, Antarctica. The chicks were sampled at the end of the chick-rearing period, after most growth has already occurred, to minimize any growth effect on blood $\delta^{15} \mathrm{~N}$ values (Sears et al. 2009). During this period, food is only provided by the adults, and therefore the isotopic values of chick blood will reflect their diet and the foraging locations of adults. Chicks were selected at random from each site and whole blood was collected via venipuncture, stored in $70 \%$ ethanol, and then at $-20^{\circ} \mathrm{C}$ until analysis. Storage in $70 \%$ ethanol does not alter the bulk $\delta^{15} \mathrm{~N}$ values of blood (Hobson et al. 1997, Bugoni et al. 2008), while some studies reported a slight increase in bulk $\delta^{13} \mathrm{C}$ values of blood. Lipids were not removed from these samples, as it has been shown that the low lipid content of blood does not require lipid extraction prior to isotopic analysis (Cherel et al. 2005).

Sample preparation for CSIA. Prior to CSIA, ethanol was evaporated and the whole blood samples were freeze-dried. Blood samples from 3 chicks from each species were selected for CSIA. Preparation of blood samples for CSIA followed previous protocols for muscle samples (e.g. Popp et al. 2007, Hannides et al. 2009). Only an overview of the CSIA method is pre-

Table 1. Foraging characteristics and blood $\delta^{13} \mathrm{C}$ and $\delta^{15} \mathrm{~N}$ values (means $\pm \mathrm{SD}$ ) of penguin species during the chick-rearing period

\begin{tabular}{|c|c|c|c|c|c|c|c|}
\hline Species & Locations & $\begin{array}{l}\text { Foraging } \\
\text { areas }\end{array}$ & $\begin{array}{l}\text { Foraging } \\
\text { range }(\mathrm{km})\end{array}$ & Chick diet & $\delta^{13} \mathrm{C}(\% \circ)^{\mathrm{a}}$ & $\delta^{15} \mathrm{~N}(\%)^{\mathrm{a}}$ & References \\
\hline $\begin{array}{l}\text { Eudyptes chrysocome moseleyi, } \\
\text { northern rockhopper penguin }\end{array}$ & $\begin{array}{c}\text { Amsterdam } \\
\text { Island } \\
\left(37.8^{\circ} \mathrm{S}\right)\end{array}$ & $\begin{array}{l}\text { Subtropical } \\
\text { Zone }\end{array}$ & $<10$ & $\begin{array}{c}\text { Squid \& } \\
\text { crustaceans }\end{array}$ & $\begin{array}{c}-19.5 \pm 0.3 \\
(\mathrm{n}=10)\end{array}$ & $\begin{array}{l}9.2 \pm 0.3 \\
(\mathrm{n}=10)\end{array}$ & $\begin{array}{l}\text { Tremblay \& Cherel } \\
(2003)\end{array}$ \\
\hline $\begin{array}{l}\text { Eudyptes chrysocome chrysocome, } \\
\text { southern rockhopper penguin }\end{array}$ & $\begin{array}{l}\text { Crozet } \\
\text { Islands } \\
\left(46.42^{\circ} \mathrm{S}\right)\end{array}$ & $\begin{array}{l}\text { Polar Frontal } \\
\text { Zone }\end{array}$ & $<10$ & Crustaceans & $\begin{array}{l}-21.2 \pm 0.1 \\
(\mathrm{n}=10)\end{array}$ & $\begin{array}{l}6.8 \pm 0.3 \\
(\mathrm{n}=10)\end{array}$ & $\begin{array}{l}\text { Tremblay \& Cherel } \\
(2003)\end{array}$ \\
\hline $\begin{array}{l}\text { Aptenodytes patagonicus, } \\
\text { king penguin }\end{array}$ & $\begin{array}{l}\text { Crozet } \\
\text { Islands } \\
\left(46.42^{\circ} \mathrm{S}\right)\end{array}$ & $\begin{array}{l}\text { Polar Front } \\
\left(50^{\circ} \mathrm{S}\right)\end{array}$ & $340-450$ & Pelagic fish & $\begin{array}{l}-22.6 \pm 0.1 \\
(\mathrm{n}=10)\end{array}$ & $\begin{array}{c}10.3 \pm 0.2 \\
(\mathrm{n}=10)\end{array}$ & $\begin{array}{l}\text { Cherel et al. (1993) } \\
\text { Charrassin \& Bost } \\
(2001)\end{array}$ \\
\hline $\begin{array}{l}\text { Pygoscelis adeliae, } \\
\text { Adélie penguin }\end{array}$ & $\begin{array}{l}\text { Adélie Land } \\
\quad\left(66.7^{\circ} \mathrm{S}\right)\end{array}$ & $\begin{array}{l}\text { Antarctic } \\
\text { Zone }\end{array}$ & $<50$ & $\begin{array}{l}\text { Crustaceans } \\
\quad \text { (fish) }\end{array}$ & $\begin{array}{c}-24.8 \pm 0.5 \\
(\mathrm{n}=9)\end{array}$ & $\begin{array}{l}10.1 \pm 0.8 \\
(\mathrm{n}=9)\end{array}$ & $\begin{array}{l}\text { Wienecke et al. } \\
(2000)\end{array}$ \\
\hline
\end{tabular}




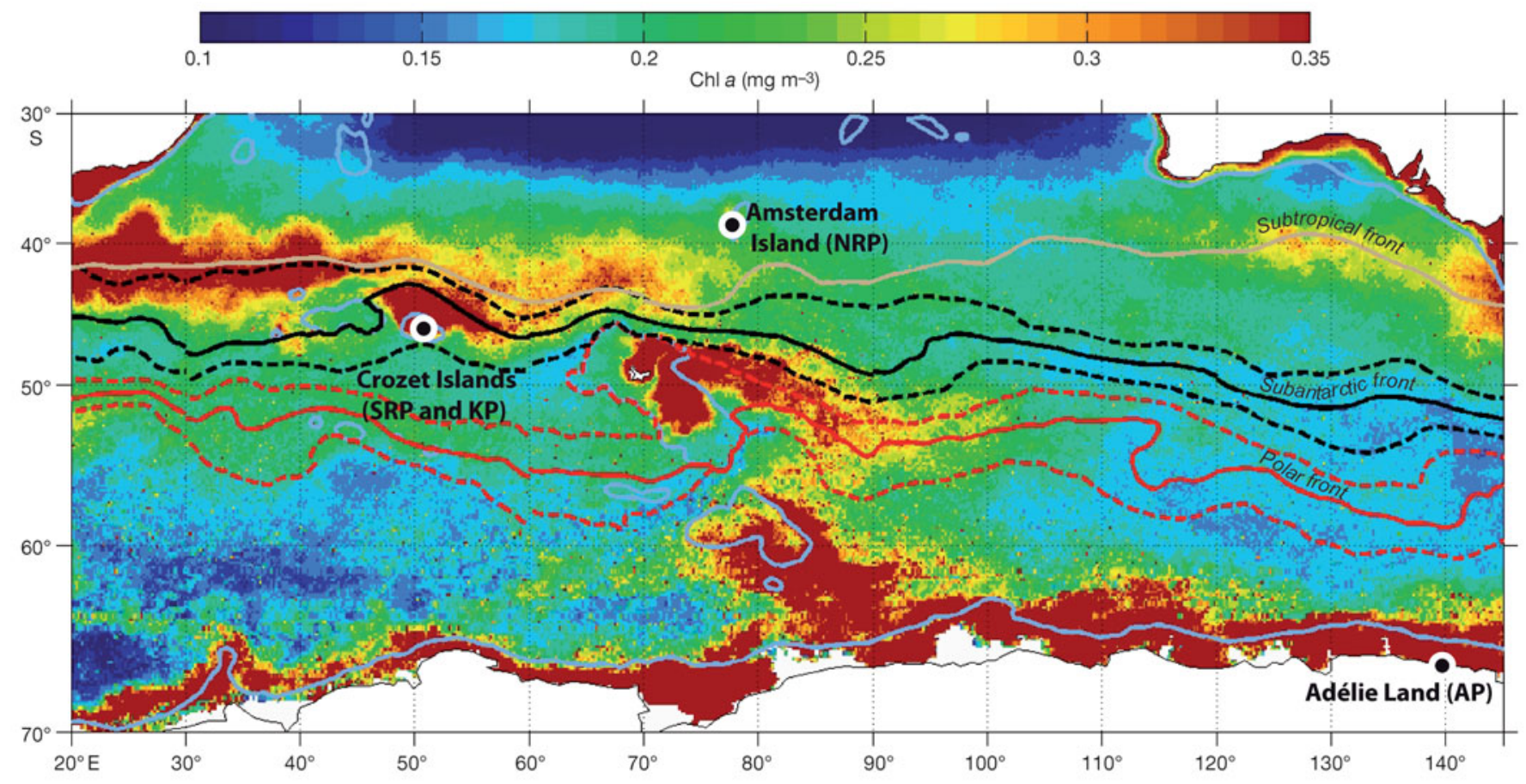

Fig. 1. Sampling locations $(\bullet)$ of the 4 penguin species in the Southern Ocean: northern rockhopper penguins (NRP, Eudyptes chrysocome moseleyi), southern rockhopper penguins (SRP, Eudyptes chrysocome chrysocome), king penguins (KP, Aptenodytes patagonicus), and Adélie penguins (AP, Pygoscelis adeliae). Mean chlorophyll distribution averaged over the period from October 1997 to October $2002\left(\mathrm{mg} \mathrm{m}^{-3}\right.$, color scale) in the Southern Ocean overlaid with the Southern Ocean fronts. Mean ocean front positions (subantarctic and polar) are mapped using sea surface height (SSH) observations (adopted from Sokolov \& Rintoul 2007, in press). The Subtropical front position (light brown line) is based on the temperature criteria in Sokolov \& Rintoul (2002) and is mapped using WOCE global hydrographic climatology (Gouretski \& Koltermann 2004). The 2000 m bathymetric contour is indicated by a light blue line

sented here; we refer the reader to Popp et al. (2007) and Hannides et al. (2009) for specific details on materials and methods. To hydrolyze the samples, 4 to $6 \mathrm{mg}$ of dried (whole) blood were transferred to hightemperature reaction vials, $\sim 1 \mathrm{ml} 6 \mathrm{~N} \mathrm{HCl}$ added, heated to $150^{\circ} \mathrm{C}$ for $70 \mathrm{~min}$, and cooled. These hydrolysates were evaporated and the residue re-dissolved in $1 \mathrm{ml} 0.01 \mathrm{~N} \mathrm{HCl}$ and the solution filtered $(0.2 \mu \mathrm{m})$. The solution was further purified using the cationexchange method of Metges et al. (1996). Prior to the derivatization, samples were re-acidified.

AA derivatization included esterification of the carboxyl terminus followed by trifluoracetylation of the amine group. Samples were esterified using 4:1 isopropanol:acetyl chloride and by heating at $110^{\circ} \mathrm{C}$ for $60 \mathrm{~min}$. Samples were dried and acylated by the addition of 3:1 methylene chloride:trifluoroacetic anhydride (TFAA) and heating at $100^{\circ} \mathrm{C}$ for $15 \mathrm{~min}$. The derivatized samples were further purified using the method of Ueda et al. (1989). Finally, to ensure complete derivatization of the samples, the TFAA acylation step was repeated. The resulting trifluoroacetic (TFA) derivatives were stored in 3:1 methylene chloride: TFAA at $4^{\circ} \mathrm{C}$.
Compound-specific $\delta^{15} \mathbf{N}$ stable isotope analyses. The $\delta^{15} \mathrm{~N}$ values of individual AAs were analyzed by isotope ratio monitoring gas chromatography-mass spectrometry (IRMS) using a ThermoFinnigan DeltaPlus XP mass spectrometer interfaced to a Trace GC gas chromatograph through a GC-C III combustion furnace $\left(980^{\circ} \mathrm{C}\right)$, reduction furnace $\left(680^{\circ} \mathrm{C}\right)$, and liquid nitrogen cold trap. L-2-aminoadipic acid (AAA), for which the $\delta^{15} \mathrm{~N}$ value was known, was co-injected as an internal reference. Samples plus the AAA reference compound were dried and diluted with ethyl acetate prior to injection (1 to $3 \mu l$, split/splitless, 5:1 split ratio) onto a $50 \mathrm{~m}$ HP Ultra-2 column $(0.32 \mathrm{~mm}$ inner diameter, $0.5 \mu \mathrm{m}$ film thickness) at an injector temperature of $180^{\circ} \mathrm{C}$ and a constant helium flow rate of $2 \mathrm{ml}$ $\mathrm{min}^{-1}$. The column oven was initially held at $50^{\circ} \mathrm{C}$ for $2 \mathrm{~min}$, ramped to $190^{\circ} \mathrm{C}$ at $8^{\circ} \mathrm{C} \mathrm{min}{ }^{-1}$ and then to $280^{\circ} \mathrm{C}$ at $10^{\circ} \mathrm{C} \mathrm{m^{-1 }}$, and finally held at $280^{\circ} \mathrm{C}$ for $10 \mathrm{~min}$. The irmGCMS method allowed isotopic determination of alanine, glycine, leucine, isoleucine, proline, aspartic acid, glutamic acid, phenylalanine, and histidine. Samples were analyzed at least in triplicate, and the measured isotopic ratios were normalized to the $\delta^{15} \mathrm{~N}$ value of the AAA reference peak in each chromatogram. 
Reproducibility associated with these isotopic measurements averaged $0.8 \%$ and ranged from 0.1 to $1.8 \%$. All $\delta^{15} \mathrm{~N}$ values are reported relative to atmospheric $\mathrm{N}_{2}$ (air).

Sample preparation for compound-specific carbon isotope analysis. For $\delta^{13} \mathrm{C}$ measurements of individual total hydrolyzable AAs (THAA), 2.3 to $7.5 \mathrm{mg}$ of freeze-dried blood was homogenized and hydrolyzed at $110^{\circ} \mathrm{C}$ in $1 \mathrm{ml} 6 \mathrm{M} \mathrm{HCl}$ in screw-cap vials with a $\mathrm{N}_{2}$ headspace. After addition of an internal standard (Norleucine), the hydrolysate was evaporated under a gentle $\mathrm{N}_{2}$ flow at $60^{\circ} \mathrm{C}$. The dried THAA extracts were re-dissolved in $\mathrm{MQ}$ water and stored frozen $\left(-20^{\circ} \mathrm{C}\right)$. Prior to analyses on the HPLC-IRMS, samples were centrifuged at $3000 \mathrm{rpm}$ (1603 g) for $10 \mathrm{~min}$.

Compound-specific $\boldsymbol{\delta}^{\mathbf{1 3}} \mathbf{C}$ stable isotope analyses. The $\delta^{13} \mathrm{C}$ values of specific AAs were analyzed using a modified HPLC-IRMS method, based on the protocol suggested by McCullagh et al. (2006). A Surveyor HPLC was coupled to a Finnigan Delta V IRMS via the LC Isolink interface (Thermo Electron). AA separation was performed using a Primesep A column $(3.2 \times 250 \mathrm{~mm}$, particle size $5 \mu \mathrm{m}$, pore size $100 \AA$, Sielc Technologies) by applying a gradient program with 2 mobile phases (100\% $\mathrm{H}_{2} \mathrm{O}$ [Milli-Q] and $0.2 \%$ [v/v] $\mathrm{H}_{2} \mathrm{SO}_{4}$, respectively), supplied by a pump with high precision proportioning valves to control mobile phase composition. Pure $\mathrm{H}_{2} \mathrm{O}$ was used for the first $22 \mathrm{~min}$, after which the mobile phase was switched to linearly increase to $0.2 \%$ $\mathrm{H}_{2} \mathrm{SO}_{4}$ after $75 \mathrm{~min}$. The mobile phase then remained at $0.2 \% \mathrm{H}_{2} \mathrm{SO}_{4}$ for $40 \mathrm{~min}$ and switched back to $100 \%$ $\mathrm{H}_{2} \mathrm{O}$ until the end of the run (138 min). All mobile phase and reagent solutions were ultrasonically degassed under reduced pressure prior to use, and stock solutions were continuously purged with He during analysis. The column flow rate was kept stable at $500 \mu \mathrm{l} \mathrm{min}{ }^{-1}$ at $22^{\circ} \mathrm{C}$. All samples were analyzed with $10 \mu \mathrm{l}$ partial loop injections using a $50 \mu$ linjection loop.

Separated AAs eluting from the HPLC were oxidized online with a mixture of $0.67 \mathrm{M}$ sodium peroxidisulfate (Merck, Darmstadt) and 1.5 M phosphoric acid (Fluka Sigma Aldrich) at $99.9^{\circ} \mathrm{C}$. The flow of both reagents was kept at $30 \mu \mathrm{l} \mathrm{min}{ }^{-1}$. The resulting $\mathrm{CO}_{2}$ was extracted from the liquid in a phase separator with a $1 \mathrm{ml} \mathrm{He}$ flow (see Krummen et al. 2004). The He containing the $\mathrm{CO}_{2}$ from the individual AAs was dried over a Nafion tube and subsequently transferred to the IRMS through an open split.

To calibrate $\delta^{13} \mathrm{C}$ values of AAs, a mixture of individual AA laboratory reference compounds was used. The $\delta^{13} \mathrm{C}$ values of these compounds were determined independently with an EA (elemental analysis)-IRMS using IAEA-CH-6 and an internal laboratory reference compound (Schimmelmann acetanilide). The $\delta^{13} \mathrm{C}$ value of each of these compounds was previously calibrated using NBS 19 and L-SVEC on the VPDB (Vienna PeeDee Belemnite) scale, where NBS-19 and L-SVEC are defined as exactly +1.95 and $-46.6 \%$, respectively (Coplen et al. 2006). Individual AA calibration was required because the offset in $\delta^{13} \mathrm{C}$ values between measurements made on the HPLC-IRMS and those obtained on the EA-IRMS were different for some AAs (corrections ranged between $-3.8 \%$ for glycine and $+5.7 \%$ for threonine). Repeated analyses of glycine over a range of concentrations (200 to $1000 \mathrm{ng} \mathrm{C}$ ) showed excellent reproducibility, with the $\delta^{13} \mathrm{C}$ value averaging $-39.8 \pm 0.15 \%$ o $(n=15)$.

The Primsep A column is a mixed-mode column, with negatively charged functional groups due to the embedded anionic ion-pairing reagent. AAs with $>1$ charge state within the $\mathrm{pH}$ range (e.g. aspartic acid and glutamic acid) have retention times that shift as a function of the mobile phase $\mathrm{pH}$, which can result in co-elution of AA peaks. Unfortunately these analytical conditions resulted in co-eluation of glutamic acid, cysteine and serine, as well as isoleucine, norleucine and leucine. Therefore isotopic values of these compounds were considered in the present study. Six AAs were analyzed for both $\delta^{15} \mathrm{~N}$ and $\delta^{13} \mathrm{C}$ values (alanine, aspartic acid, histidine, glycine, phenylalanine, and proline).

Statistical modeling of AA $\delta^{\mathbf{1 5}} \mathbf{N}$ values. Statistical analyses must account for the different sources of variation induced by the sampling strategy, and for the small number of samples analyzed. First, blood samples were collected from several individuals per species ( 2 or 3 individuals selected at random). Secondly, several replicates were performed on each blood sample (at least 3 replicates, but some AA isotope data were removed because of peak co-elution). Simple averages cannot account for the within-individual variability and for the between-individual variability. On the contrary, linear mixed-effects models (LME model; Pinheiro \& Bates 2000) are well suited to deal with unbalanced sampling schemes, and they allow different sources of variation to be included. In the present study, we had to consider several replicates per blood sample and several individuals per species. Therefore, LME models were fitted to the $\delta^{15} \mathrm{~N}$ values of individual AAs, and data were grouped by individuals (measurement replicates) and by species. The individual effect was treated as random variation around a population mean. The species effects represent average characteristics of the populations of the 4 penguin species (i.e. the fixed effect in LME terms). These models allowed us to predict population values of $\mathrm{AA} \delta^{15} \mathrm{~N}$ for each penguin species. These predicted values were then used as the best estimates, as they accounted for the different sources of variation. Parameter estimation used the maximum-likelihood method, and all computations and tests were performed in S-PLUS. 
Comparison of source AA $\delta^{15} \mathrm{~N}$ values and TL estimates. These LME models were used to predict population $\delta^{15} \mathrm{~N}$ values of glutamic acid $\left(\delta^{15} \mathrm{~N}_{\text {glu }}\right)$ and phenylalanine $\left(\delta^{15} \mathrm{~N}_{\text {phe }}\right)$ for each species. We assumed: (1) that phenylalanine does not fractionate between TLs (i.e. a source AA), (2) that glutamic acid demonstrates a step-wise trophic enrichment (i.e. a trophic AA) from one TL to the next above the primary producers, and therefore (3) that the difference between glutamic acid and phenylalanine $\left(\Delta \delta^{15} \mathrm{~N}_{\text {glu-phe }}\right)=\delta^{15} \mathrm{~N}_{\text {glu }}-\delta^{15} \mathrm{~N}_{\text {phe }}$ can be considered as an index of TL for each penguin species (see Schmidt et al. 2004, Hannides et al. 2009). We computed $\Delta \delta^{15} \mathrm{~N}_{\text {glu-phe }}$ for each replicate and calculated population values of this parameter using a supplementary LME model. These population-predicted values of $\Delta \delta^{15} \mathrm{~N}_{\text {glu-phe }}$ were used to compare the relative TLs of each penguin species.

The TL for each penguin ( $\mathrm{TL}_{\text {penguin) }}$ species can be estimated from the equation of Hannides et al. (2009):

$\mathrm{TL}_{\text {penguin }}=\left[\frac{\left(\Delta \delta^{15} \mathrm{~N}_{\text {glu-phe }}\right)_{\text {penguin }}-\left(\Delta \delta^{15} \mathrm{~N}_{\text {glu-phe }}\right)_{\text {phytoplankton }}}{\mathrm{TEF}}\right]+1$ from a shift in 1 TL. Eq. (1) has 3 unknown variables: TL $L_{\text {penguin, }}\left(\Delta \delta^{15} \mathrm{~N}_{\text {glu-phe }}\right)_{\text {phytoplankton, }}$ and TEF. The TEF has been determined directly and indirectly to be $\sim 7 \%$ for samples of fish, mollusk and crustacean muscle tissue and whole organisms (McClelland \& Montoya 2002, McClelland et al. 2003, Schmidt et al. 2004, Chikaraishi et al. 2007, Popp et al. 2007). The value of $\left(\Delta \delta^{15} \mathrm{~N}_{\text {glu-phe }}\right)_{\text {phytoplankton }}$ is assumed to be equal to $4 \%$. A $\left(\Delta \delta^{15} \mathrm{~N}_{\text {glu-phe }}\right)_{\text {phytoplankton }}$ value of $\sim 4 \%$ has been found for marine green microalgae (McClelland \& Montoya 2002), cyanobacteria (McClelland et al. 2003), and brown and red macroalgae (Chikaraishi et al. 2007), where TEF is the trophic enrichment factor that results

suggesting that these AAs are biosynthesized and metabolized by similar pathways in these diverse photoautotrophs. Although the TEF has not yet been rigorously tested, a value of 7 has produced reasonable TL estimates for marine zooplankton (Hannides et al. 2009), krill (Schmidt et al. 2004), yellowfin tuna (Popp et al. 2007), and gastropods (Chikaraishi et al. 2007). Notably none of these studies has examined the isotopic compositions of AAs in blood.

\section{RESULTS}

\section{Patterns in $\delta^{15} \mathbf{N}$ AA values}

Bulk $\delta^{15} \mathrm{~N}$ values ranged 3.7\%o among all the penguin blood samples (Table 2; Cherel \& Hobson 2007). The $\delta^{15} \mathrm{~N}$ values of AAs isolated from penguin chick blood ranged from -0.2 to $+26.0 \%$ (Figs. $2 \& 3$, Table 2 ,). The trophic AAs (glutamic acid, alanine, aspartic acid, isoleucine, leucine and proline; mean: $17.9 \pm 3.0 \%$ ) were enriched in ${ }^{15} \mathrm{~N}$ relative to the source AAs (glycine, phenylalanine and histidine; mean: $5.1 \pm 3.5 \%$ ) (Table 2). Aspartic acid (mean: $14.7 \pm 2.1 \%$ ) showed the least ${ }^{15} \mathrm{~N}$ enrichment of the trophic AAs. Among the source AAs, glycine (gly) (mean: $9.2 \pm 2.8 \%$ ) was enriched in ${ }^{15} \mathrm{~N}$ relative to phenylalanine (mean: $2.5 \pm 1.2 \%$ ), and $\delta^{15} \mathrm{~N}_{\mathrm{gly}}$ values did not reflect the species-specific patterns observed in $\delta^{15} \mathrm{~N}_{\text {phe }}$ values (Table 2, Fig. 2). Except for glycine and aspartic acid, the patterns observed in AA $\delta^{15} \mathrm{~N}$ values of penguin chicks followed previous trends in trophic and source AAs isotopic values measured in marine invertebrates and fish (McClelland \& Montoya 2002, McClelland et al. 2003, Schmidt et al. 2004, Chikaraishi et al. 2007, Popp et al. 2007, Hannides et al. 2009).

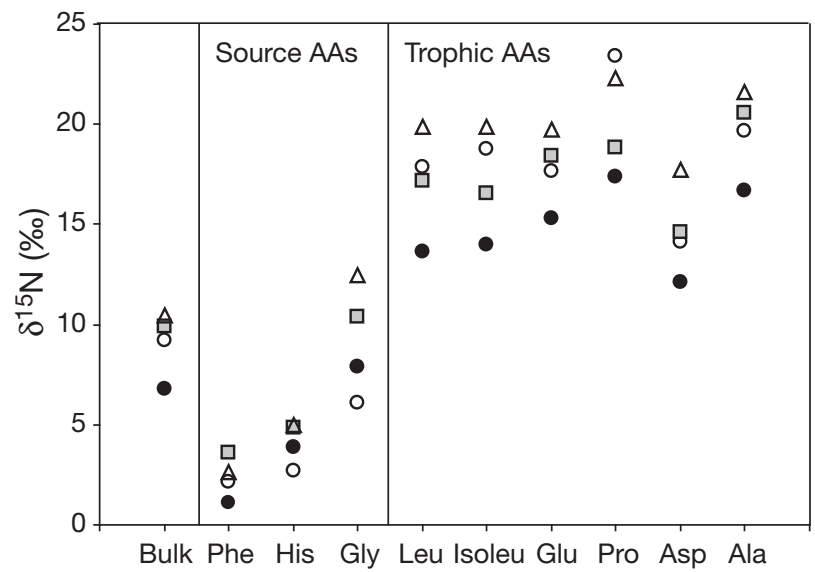

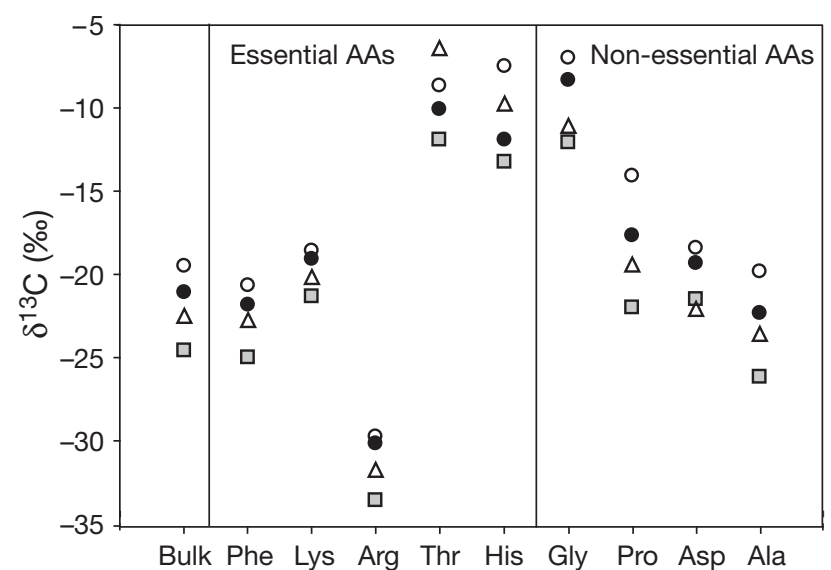

Fig. 2. Stable isotope values $\left(\delta^{15} \mathrm{~N}\right.$ to the left and $\delta^{13} \mathrm{C}$ to the right) of bulk and individual amino acids (AAs) of the 4 penguin species. O: northern rockhopper penguin Eudyptes chrysocome moseleyi; •: southern rockhopper penguin Eudyptes chrysocome chrysocome; $\Delta$ : king penguin Aptenodytes patagonicus; $\square$ : Adélie penguin Pygoscelis adeliae. Note: for N, mean values are predicted values (see Table 2). Phe: phenylalanine; His: histidine; Gly: glycine; Leu: leucine; Isoleu: isoleucine; Glu: glutamic acid; Pro: proline; Asp: aspartic acid; Ala: alanine; Lys: lysine; Arg: arginine; Thr: threonine 
Table 2. $\delta^{15} \mathrm{~N}$ values of the bulk sample and isolated amino acids (full designations, see Fig. 2 legend) of blood collected from penguin chicks from the Southern Ocean. Data for the different individuals per species are indicated (2 ind. for both NRP and SRP; 3 for both KP and AP). Source amino acids are indicated by bold print. NC: not considered because of peak co-elution. Linear mixed-effect (LME) estimates for each species (mean \pm SE) were calculated with LME models that accounted for the heterogeneity of the data set (see 'Materials and methods')

\begin{tabular}{|c|c|c|c|c|c|c|c|c|c|c|}
\hline & \multirow[t]{2}{*}{$\begin{array}{c}\text { Bulk } \delta^{15} \mathrm{~N} \\
(\%)\end{array}$} & \multirow[b]{2}{*}{ Phe } & \multirow[b]{2}{*}{ His } & \multirow[b]{2}{*}{ Gly } & \multicolumn{3}{|c|}{ - Amino acid $\delta^{15} \mathrm{~N}$ values $(\%)$} & \multirow[b]{2}{*}{ Pro } & \multirow[b]{2}{*}{ Asp } & \multirow[b]{2}{*}{ Ala } \\
\hline & & & & & Leu & Isoleu & Glu & & & \\
\hline \multicolumn{11}{|c|}{ Eudyptes chrysocome moseleyi, northern rockhopper penguin (NRP), $37.8^{\circ} \mathrm{S}$} \\
\hline \multirow{4}{*}{ NRP 1} & 9.2 & 2.5 & 3.0 & 6.9 & 18.5 & 19.7 & 19.0 & 23.9 & 14.6 & 20.3 \\
\hline & & 3.1 & 2.9 & 5.6 & 17.2 & 17.4 & 18.3 & 22.4 & 14.0 & 19.8 \\
\hline & & 1.6 & 0.9 & 3.9 & 16.1 & 17.7 & 16.0 & 20.4 & 13.8 & 18.7 \\
\hline & & 1.7 & 2.2 & 4.7 & 17.2 & 18.1 & 16.3 & 23.6 & 13.0 & 19.8 \\
\hline \multirow{4}{*}{ NRP 2} & 9.2 & 2.4 & 1.2 & 5.7 & 18.4 & 19.5 & 17.5 & 21.8 & 13.3 & 18.5 \\
\hline & & 1.5 & 2.9 & 5.5 & 18.3 & 19.4 & 18.0 & 23.8 & 14.1 & 19.3 \\
\hline & & 2.6 & 3.6 & 7.7 & 18.2 & 17.8 & 16.2 & 25.4 & 14.7 & 20.1 \\
\hline & & 1.7 & 5.1 & 8.8 & 18.8 & 20.4 & 19.9 & 26.0 & 15.4 & 20.7 \\
\hline LME & Estimate & $2.1 \pm 0.5$ & $2.7 \pm 1.4$ & $6.1 \pm 0.8$ & $17.8 \pm 0.5$ & $18.8 \pm 0.7$ & $17.7 \pm 0.6$ & $23.4 \pm 0.7$ & $14.1 \pm 0.5$ & $19.7 \pm 0.4$ \\
\hline \multicolumn{11}{|c|}{ Eudyptes chrysocome chrysocome, southern rockhopper penguin (SRP), $46.7^{\circ} \mathrm{S}$} \\
\hline \multirow[t]{4}{*}{ SRP 1} & 6.8 & 1.1 & 2.7 & 9.6 & 12.8 & 12.8 & 14.8 & 16.4 & 12.0 & 16.8 \\
\hline & & 1.7 & 1.0 & 7.9 & 12.7 & 13.2 & 14.0 & 16.5 & 12.9 & 16.3 \\
\hline & & 1.4 & 1.3 & 7.8 & 13.1 & 14.4 & 14.9 & 17.4 & 11.9 & 15.8 \\
\hline & & 1.1 & 2.2 & 7.9 & 12.7 & 12.6 & 15.8 & 16.0 & 11.1 & 16.4 \\
\hline \multirow[t]{3}{*}{ SRP 2} & 6.8 & -0.2 & 4.7 & 6.4 & 13.5 & 14.4 & 15.5 & 19.0 & 12.0 & 16.6 \\
\hline & & 1.8 & 5.9 & 8.6 & 15.0 & 15.2 & 16.1 & 18.0 & 12.4 & 17.3 \\
\hline & & 1.2 & 7.6 & 7.3 & 14.8 & 14.4 & 15.5 & 17.5 & 12.4 & 17.3 \\
\hline LME & Estimate & $1.1 \pm 0.5$ & $3.9 \pm 1.4$ & $7.9 \pm 0.8$ & $13.6 \pm 0.5$ & $13.9 \pm 0.8$ & $15.2 \pm 0.6$ & $17.3 \pm 0.7$ & $12.1 \pm 0.5$ & $16.6 \pm 0.4$ \\
\hline \multicolumn{11}{|c|}{ Aptenodytes patagonicus, king penguin (KP), $50.0^{\circ} \mathrm{S}$} \\
\hline \multirow[t]{4}{*}{ KP 1} & 10.4 & 2.8 & NC & 13.6 & 19.8 & 21.5 & 20.2 & 22.4 & 18.4 & 22.3 \\
\hline & & 3.0 & NC & 14.5 & $\mathrm{NC}$ & $\mathrm{NC}$ & 22.0 & 24.6 & 19.3 & 22.9 \\
\hline & & 4.1 & 7.7 & 12.2 & 20.0 & 21.8 & 21.5 & 23.2 & 18.0 & 21.3 \\
\hline & & 2.5 & 5.3 & 11.5 & 20.1 & 20.4 & 21.4 & 22.1 & 18.2 & 21.0 \\
\hline \multirow[t]{3}{*}{ KP 2} & 10.5 & 2.5 & 5.0 & NC & 19.6 & $\mathrm{NC}$ & 19.7 & 23.1 & $\mathrm{NC}$ & $\mathrm{NC}$ \\
\hline & & 2.0 & 4.5 & NC & 20.1 & $\mathrm{NC}$ & 19.5 & 23.1 & 18.1 & $\mathrm{NC}$ \\
\hline & & 1.0 & 3.0 & NC & 19.9 & $\mathrm{NC}$ & 17.4 & 21.2 & $\mathrm{NC}$ & $\mathrm{NC}$ \\
\hline \multirow[t]{3}{*}{ KP 3} & 10.5 & 2.7 & 4.4 & NC & 19.3 & 18.6 & 18.8 & 20.7 & 15.9 & 20.6 \\
\hline & & 2.3 & 2.3 & 11.2 & 18.9 & 18.4 & 18.7 & 21.2 & 16.4 & 21.2 \\
\hline & & 3.8 & 5.9 & 12.8 & 20.9 & $\mathrm{NC}$ & 20.0 & 22.4 & 17.8 & 22.3 \\
\hline LME & Estimate & $2.6 \pm 0.5$ & $4.9 \pm 1.3$ & $12.6 \pm 0.9$ & $19.8 \pm 0.4$ & $20.0 \pm 0.8$ & $19.9 \pm 0.6$ & $22.4 \pm 0.7$ & $17.7 \pm 0.5$ & $21.7 \pm 0.4$ \\
\hline \multicolumn{11}{|c|}{ Pygoscelis adeliae, Adélie penguin (AP). $66.7^{\circ} \mathrm{S}$} \\
\hline \multirow[t]{3}{*}{ AP 1} & 9.5 & 3.1 & 9.0 & 8.8 & 16.7 & 15.8 & 18.6 & 18.6 & 14.4 & 21.0 \\
\hline & & 3.8 & 5.7 & 9.7 & 17.2 & 15.4 & 18.3 & 18.7 & 13.6 & 21.8 \\
\hline & & 2.9 & 5.7 & 7.9 & 16.4 & 16.2 & 18.2 & 18.3 & 13.8 & 20.1 \\
\hline \multirow[t]{4}{*}{ AP 2} & 10.0 & 1.4 & 1.7 & 10.9 & 16.5 & 16.0 & 17.4 & 17.3 & 14.0 & 19.4 \\
\hline & & 3.7 & 3.6 & 13.2 & 18.2 & 17.9 & 20.1 & 19.5 & 15.3 & 21.9 \\
\hline & & 2.8 & 3.8 & 11.5 & 17.3 & 17.6 & 18.2 & 18.2 & 15.0 & 20.3 \\
\hline & & 2.9 & 2.7 & 11.0 & 17.0 & 16.3 & 18.6 & 18.0 & 14.8 & 21.1 \\
\hline AP 3 & 10.3 & 4.7 & 5.7 & 9.4 & 17.3 & 17.0 & 17.9 & 19.1 & 15.5 & 19.4 \\
\hline & & 4.3 & 6.5 & 11.3 & 17.8 & 17.1 & 19.7 & 20.9 & 16.1 & 20.9 \\
\hline & & 5.1 & 5.4 & 11.5 & 17.4 & 16.3 & 17.8 & 19.3 & 14.6 & 20.1 \\
\hline LME & Estimate & $3.5 \pm 0.5$ & $5.2 \pm 0.9$ & $10.5 \pm 0.5$ & $17.2 \pm 0.3$ & $16.5 \pm 0.5$ & $18.5 \pm 0.4$ & $18.8 \pm 0.5$ & $14.7 \pm 0.3$ & $20.6 \pm 0.2$ \\
\hline
\end{tabular}

The LME models fitted to the $\delta^{15} \mathrm{~N}_{\text {phe }}$ and to the $\delta^{15} \mathrm{~N}_{\text {glu }}$ data indicated that the species effect was significant ( $\mathrm{p}=0.022$ and $\mathrm{p}=0.002$, respectively) and that these values differed then by penguin species (Table 2). LME values with their standard errors (SE) for the 4 penguin species are shown graphically in
Fig. 3 and are listed in Table 2. AP had the highest LME estimated $\delta^{15} \mathrm{~N}_{\text {phe }}$ values $(3.5 \pm 0.3 \%$ ), whereas SRP had the lowest LME estimated values $(1.1 \pm 0.5 \%)$. NRP had LME predicted $\delta^{15} \mathrm{~N}_{\text {phe }}$ values $(2.1 \pm 0.5 \%$ ) higher than SRP $(1.1 \pm 0.5 \%)$, while KP had moderate $\delta^{15} \mathrm{~N}_{\text {phe }}$ values $(2.6 \pm 0.5 \%)$. 


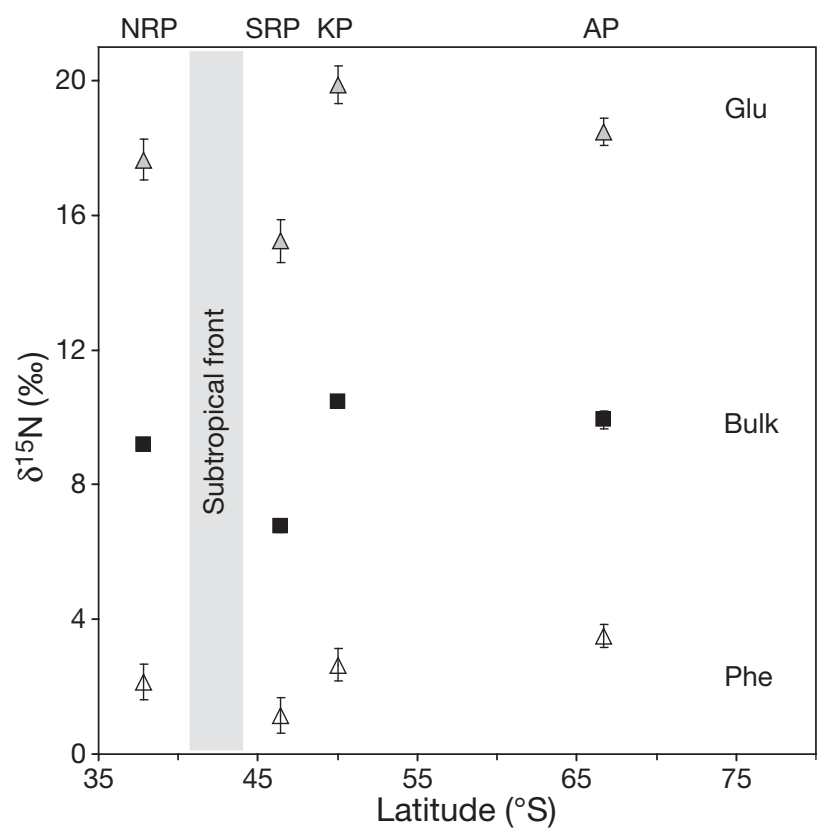

Fig. 3. Variations of $\delta^{15} \mathrm{~N}$ values for bulk ( $\mathbf{\square}$, mean $\left.\pm \mathrm{SE}\right)$, phenylalanine $(\Delta$, Phe), and glutamic acid $(\Delta$, Glu) (predicted values $\pm S E$, see 'Materials and methods') with latitude for 4 penguin species: northern rockhopper penguin (NRP, Eudyptes chrysocome moseleyi), southern rockhopper penguin (SRP, Eudyptes chrysocome chrysocome), king penguin (KP, Aptenodytes patagonicus) and Adélie penguin (AP, Pygoscelis adeliae)

\section{Trophic level of Southern Ocean penguins}

Table 3 displays the LME estimated values for the index of TL $\Delta \delta^{15} \mathrm{~N}_{\text {glu-phe }}$ for the 4 species. The species effect was significant ( $p=0.018)$. Among penguin spe-

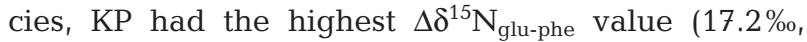
Table 3), and SRP had the lowest (14.1\%). Estimates for NRP and AP were close, with a slightly higher $\Delta \delta^{15} \mathrm{~N}_{\text {glu-phe }}$ for NRP (15.5 vs. $15.0 \%$ o).

Using Eq. (1) with a TEF of $7 \%$ and a $\Delta \delta^{15} \mathrm{~N}_{\text {glu-phe }}$ in phytoplankton of $4 \%$ provided consistent underestimates of TL $(2.6,2.4,2.9$, and 2.6 for NRP, SRP, KP, and $\mathrm{AP}$, respectively) relative to independent TL estimates based on bulk stable isotope analyses for 3 of the 4 spe- cies $(4.0,4.5$, and 3.9 for $\mathrm{SRP}, \mathrm{KP}$, and $\mathrm{AP}$, respectively; see Table 3, Cherel et al. 2008) and stomach content analyses for all the species (Table 1). Assuming that the TL estimates based on bulk stable isotope analysis are correct, a TEF for penguin chick blood was calculated. This TEF estimation is based on the LME model estimated differences $\left(\Delta \delta^{15} \mathrm{~N}_{\text {glu-pher }}\right.$ see Table 3) and a $\Delta \delta^{15} \mathrm{~N}_{\text {glu-phe }}$ of $4 \%$ for phytoplankton. Given these assumptions (which will be addressed in the 'Discussion'), the new TEF would be 3.4, 3.8, and 3.8\%o for $\mathrm{SRP}, \mathrm{KP}$, and $\mathrm{AP}$, respectively (3.6\% on average), which is less than the $7 \%$ cited in previous studies.

\section{Patterns in $\delta^{13} \mathrm{C} A \mathrm{~A}$ values}

While bulk $\delta^{13} \mathrm{C}$ values showed a range of $5.5 \%$ among the penguin samples (see Tables $1 \& 4$ ), the $\delta^{13} \mathrm{C}$ values of AAs isolated from the blood of penguin chicks ranged from -5.0 to $-34.0 \%$ (Table 4 , Figs. $2 \& 4$ ). There was no clear pattern of ${ }^{13} \mathrm{C}$ enrichment related to essential (arginine, histidine, lysine, phenylalanine, and threonine) or non-essential AAs (alanine, aspartic acid, glycine, and proline) (Table 4, Fig. 2). Instead, there were 3 general $\delta^{13} \mathrm{C}$ groups of AAs, in which 2 of the 3 groups included both essential and non-essential AAs: (1) a group of AAs with high ${ }^{13} \mathrm{C}$ enrichment (threonine, glycine, and histidine; mean: $-9.9 \pm 2.3 \%$ ), (2) an intermediate group of AAs with $\delta^{13} \mathrm{C}$ values similar to bulk $\delta^{13} \mathrm{C}$ values (proline, alanine, phenylalanine, aspartic acid, and lysine; mean: $-22.2 \pm 4.3 \%$ ), and (3) a final group of only essential AAs that were very depleted in ${ }^{13} \mathrm{C}$ (arginine; mean: $-31.3 \pm 1.6 \%$ ). The bimodal pattern observed in the $\delta^{15} \mathrm{~N}$ values of source and trophic AAs was not seen in the $\delta^{13} \mathrm{C}$ values. Instead, the $\delta^{13} \mathrm{C}$ values of all AAs decreased with increasing latitude, which mirrored the trend in bulk carbon isotope (Fig. 4a). A covariance analysis showed that a model with separate slopes for bulk and all the AAs was justified compared to a model with parallel regressions $(p=0.006)$. Slopes varied between $-0.10 \pm$ 0.03 (lysine) and $-0.26 \pm 0.03$ (proline), with 1 group of 4 AAs having parallel slopes with bulk (phenylalanine,

Table 3. Trophic position estimates from the literature, linear mixed-effect model predictions of the difference between glutamic acid and phenylalanine $\delta^{15}$ values $\left(\Delta \delta^{15} \mathrm{~N}_{\text {glu-phe }}\right.$ ) for 4 penguin species, and estimated trophic enrichment factor (TEF) between source and trophic transfer amino acids for penguin chick's blood using Eq. (1) (see 'Materials and methods' for more details). Trophic positions are from Cherel et al. (2008). NA: not available; ND: not determined

\begin{tabular}{|lccc|}
\hline Species & $\begin{array}{c}\text { Trophic } \\
\text { position }\end{array}$ & $\begin{array}{c}\text { Predicted } \Delta \delta^{15} \mathrm{~N}_{\text {glu-phe }} \\
(\% \text { ) }\end{array}$ & $\begin{array}{c}\text { Estimated TEF } \\
(\%)\end{array}$ \\
\hline Eudyptes chrysocome moseleyi, northern rockhopper penguin & $\mathrm{NA}$ & 15.5 & $\mathrm{ND}$ \\
Eudyptes chrysocome chrysocome, southern rockhopper penguin & 4.0 & 14.1 & 3.4 \\
Aptenodytes patagonicus, king penguin & 4.5 & 17.2 & 3.8 \\
Pygoscelis adeliae, Adélie penguin & 3.9 & 15.0 & 3.8 \\
\hline
\end{tabular}


Table $4 . \delta^{13} \mathrm{C}$ values of the bulk sample and isolated amino acids (full designations, see Fig. 2 legend) of blood collected from penguin chicks from the southern Indian Ocean. Normal font indicates essential amino acids and bold print indicates non-essential amino acids. NC: not considered because of peak co-elution

\begin{tabular}{|c|c|c|c|c|c|c|c|c|c|}
\hline \multirow[t]{2}{*}{ Bulk $\delta^{13} \mathrm{C}(\%)$} & \multicolumn{9}{|c|}{ Amino acid $\delta^{13} \mathrm{C}$ values (\%o) } \\
\hline & Phe & Lys & Arg & Thr & His & Gly & Pro & Asp & Ala \\
\hline \multicolumn{10}{|c|}{ Eudyptes chrysocome moseleyi, northern rockhopper penguin (NRP), $37.8^{\circ} \mathrm{S}$} \\
\hline-19.4 & -20.7 & -18.8 & -29.8 & -8.4 & -7.9 & -7.0 & -13.4 & -18.8 & -19.8 \\
\hline-19.5 & -20.6 & -18.4 & -29.5 & -8.4 & -7.9 & -7.9 & -13.3 & -18.0 & -18.7 \\
\hline-19.7 & -20.8 & -18.4 & -29.9 & -9.1 & -6.7 & -6.1 & -15.7 & -18.5 & -19.9 \\
\hline \multicolumn{10}{|c|}{ Eudyptes chrysocome chrysocome, southern rockhopper penguin (SRP), $46.7^{\circ} \mathrm{S}$} \\
\hline-21.3 & -21.9 & -19.2 & -30.4 & -10.5 & -12.7 & -8.2 & -16.8 & -19.3 & -22.8 \\
\hline-21.0 & -21.9 & -19.0 & -30.0 & -9.3 & -11.0 & -9.9 & -18.1 & -19.7 & -22.4 \\
\hline-21.0 & -21.8 & -19.1 & -30.2 & -10.4 & -12.0 & -6.9 & -18.2 & -19.1 & -21.8 \\
\hline \multicolumn{10}{|c|}{ Aptenodytes patagonicus, king penguin (KP), $50.0^{\circ} \mathrm{S}$} \\
\hline-22.5 & -22.7 & -20.1 & -31.8 & -7.9 & -9.2 & -10.4 & -18.5 & -20.9 & -24.2 \\
\hline-22.6 & -22.6 & -19.9 & -31.7 & $\mathrm{NC}$ & -10.0 & NC & -19.6 & -20.7 & -24.7 \\
\hline-22.5 & -22.9 & -20.4 & -31.9 & -5.0 & -10.0 & -11.7 & -20.2 & -24.8 & -21.7 \\
\hline \multicolumn{10}{|c|}{ Pygoscelis adeliae, Adélie penguin (AP), $66.7^{\circ} \mathrm{S}$} \\
\hline-24.5 & -25.2 & -21.2 & -33.4 & -11.5 & -14.9 & -12.2 & -22.2 & -21.5 & -26.3 \\
\hline-24.9 & -24.7 & -21.2 & -33.3 & -12.7 & -14.3 & -12.0 & -21.9 & -22.0 & -26.4 \\
\hline-24.4 & -25.2 & -21.6 & -34.0 & -11.6 & -10.6 & -12.0 & -22.0 & -21.1 & -25.7 \\
\hline
\end{tabular}

histidine, arginine, and glycine; Fig. 4a). In addition, the links between the $\delta^{13} \mathrm{C}$ values of all AAs and bulk were investigated with an extra covariance analysis: the model with separate slopes was significant $(\mathrm{p}=$ 0.002; Fig. 4b). Slopes varied between $0.52 \pm 0.18$ (threonine) and $1.51 \pm 0.18$ (proline). For 6 AAs (proline, alanine, glycine, arginine, lysine and phenylalanine), the correlation between bulk and AA-specific $\delta^{13} \mathrm{C}$ was highly significant $\left(\mathrm{R}^{2}>0.8\right.$ and $\left.\mathrm{p}<0.01\right)$, but there were clearly different patterns in the slope of the relationship (Fig. 4b). For those AAs with good correlation between bulk and AA-specific $\delta^{13} \mathrm{C}$, all non-essential AAs, except aspartic acid, had slopes $>1$, i.e. the range in $\delta^{13} \mathrm{C}$-AAs was higher than in the bulk. In contrast, for all essential amino acids the slope was $<1$. From all AAs that show good correlation with both bulk and latitude, the isotopic composition of phenylalanine was closest to that of the bulk.

\section{DISCUSSION}

\section{Penguin $\delta^{15} \mathrm{~N}$ values and foraging habitat (Hypothesis 1)}

Small but significant differences were found in $\delta^{15} \mathrm{~N}_{\text {phe }}$ values among penguin species (maximum range: $3 \%$ ). These results suggest then that phenylalanine $\delta^{15} \mathrm{~N}$ values can be used as a source AA to study the foraging habitat of penguins. NRP $\delta^{15} \mathrm{~N}_{\text {phe }}$ values were higher-even if the difference was relatively small—than SRP $\delta^{15} \mathrm{~N}_{\text {phe }}$ values $(2.1 \pm 0.5 \%$ vs. $1.1 \pm 0.5 \%$ ) , which is consistent with the hypothesis of Cherel \& Hobson (2007) i.e. that the observed differ- ence in their bulk $\delta^{15} \mathrm{~N}$ value $(2.4 \%$ ) relates in part to differences in the isotopic baseline of their foraging regions. The nitrogen isotopic composition of particulate matter is higher in the Subtropical Frontal Zone north of 40 to $45^{\circ} \mathrm{S}$ where NRP forage (Table 1 ; Tremblay 2003) than at latitudes south of $45^{\circ} \mathrm{S}$ in the SW Indian Ocean (from 5 to $-2 \%$; see Altabet \& François 1994), i.e. where SRP forage close to the Crozet Islands (Table 1). These north-south $\delta^{15} \mathrm{~N}$ gradients have also been found in modern sediments collected from the northeast Indian Ocean, which indicates that this trend has persisted for long periods of time (Altabet \& François 1994).

The highest $\delta^{15} \mathrm{~N}_{\text {phe }}$ values were observed for KP and $\mathrm{AP}$, which forage at the highest latitudes in the Southern Ocean. Previous tagging and observational data suggest that these penguins forage at the Polar Front $\left(\sim 50^{\circ} \mathrm{S}\right)$ and over the Antarctic shelf $\left(\sim 66^{\circ} \mathrm{S}\right)$, respectively (Wienecke et al. 2000, Charrassin \& Bost 2001). Both of these oceanic regions are south of the Subtropical front where one would have expected low baseline $\delta^{15} \mathrm{~N}$ values $(-1$ to $-2 \%$; Altabet \& François 1994, Lourey et al. 2003). However, several factors can lead to elevated $\delta^{15} \mathrm{~N}$ and $\delta^{13} \mathrm{C}$ values at the base of the food web. The elevated $\delta^{15} \mathrm{~N}_{\text {phe }}$ values observed in these penguins could be explained by different processes: (1) a local increase in the $\delta^{15} \mathrm{~N}$ value of the isotopic baseline (neritic vs. oceanic waters, high seasonal nutrient utilization by phytoplankton, or sea ice influence) or (2) a difference in the vertical foraging habitat, with penguins foraging on a greater proportion of mesopelagic prey that have elevated $\delta^{15} \mathrm{~N}$ values. A local region can have high baseline $\delta^{15} \mathrm{~N}$ value because 

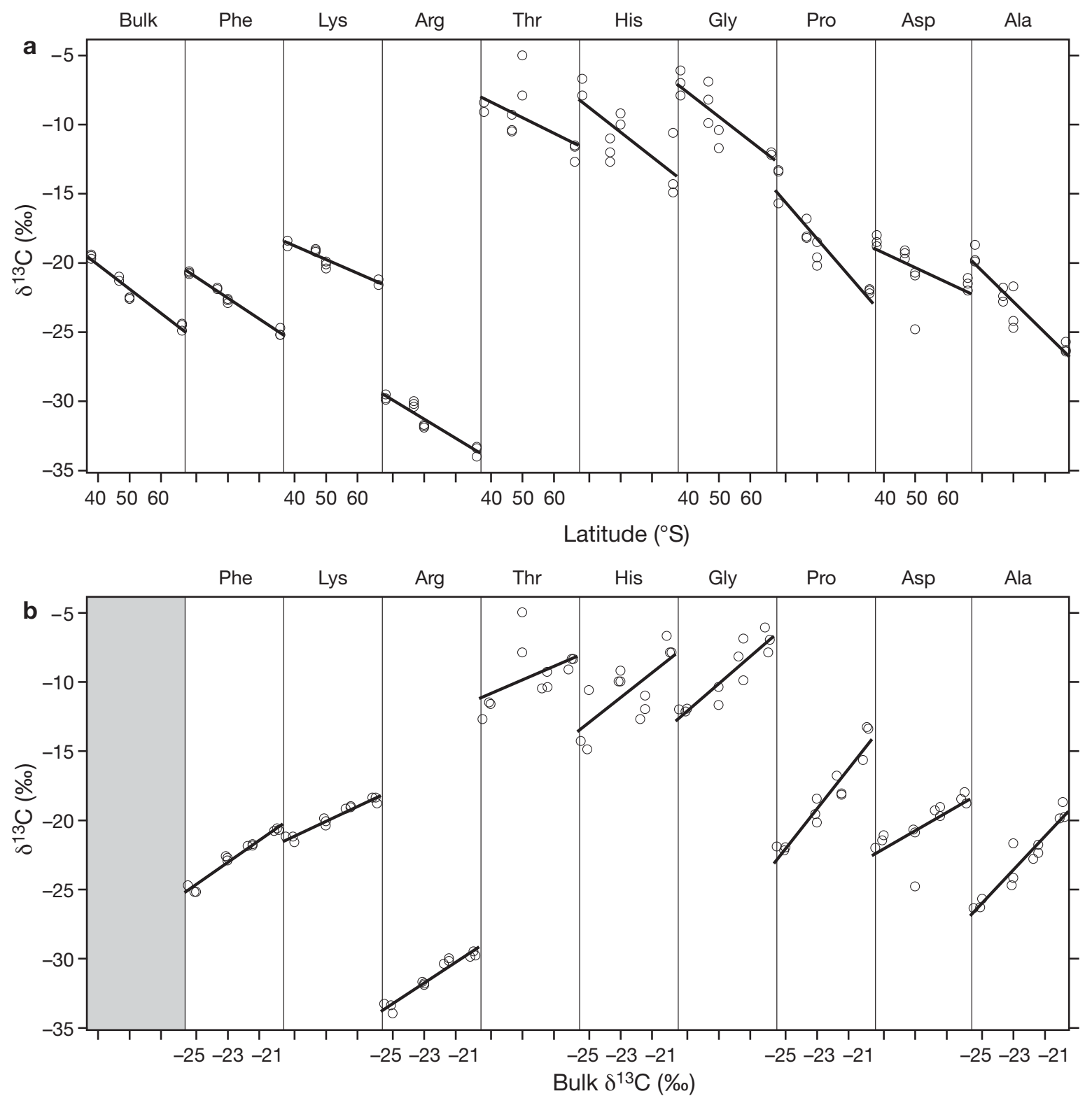

Fig. 4. Variations of (a) bulk and individual amino acid (AA) $\delta^{13} \mathrm{C}$ values (full designations, see Fig. 2 legend) with latitude and (b) of $\mathrm{AA} \delta^{13} \mathrm{C}$ values with bulk for the 4 penguin species: northern rockhopper penguin, southern rockhopper penguin, king penguin and Adélie penguin

of extensive $\mathrm{NO}_{3}{ }^{-}$utilization after a large phytoplankton bloom (Tamelander et al. 2009). From Fig. 1, high chlorophyll a concentrations are commonly found near the Crozet Islands and Adélie Land. However, the waters close to the Crozet Islands are deep and wellmixed and the injection of new $\mathrm{NO}_{3}{ }^{-}$to the surface waters will not produce high POM $\delta^{15} \mathrm{~N}$ values because the $\mathrm{NO}_{3}{ }^{-}$pool size is already large. On the other hand, over the Antarctic shelf, the water column is stratified, and nitrogen delivery to the surface waters and the subsequent uptake by phytoplankton will lead to high $\delta^{15} \mathrm{~N}$ values of the POM. Trull et al. (2008) showed a $2 \%$ increase in the $\delta^{15} \mathrm{~N}$ values of POM on Kerguelen Plateau relative to $\delta^{15} \mathrm{~N}$ values of POM collected off the plateau. The higher $\delta^{15} \mathrm{~N}$ values of POM were attributed to an increase in the uptake of $\mathrm{NO}_{3}{ }^{-}$by phytoplankton on the Kerguelen Plateau. The isotopic baseline of the waters directly surrounding the Antarctic shelf may be higher than offshore waters. AP forage within $50 \mathrm{~km}$ of their Antarctic colonies (Cherel et al. 2008). Therefore, the relatively high $\delta^{15} \mathrm{~N}_{\text {phe }}$ values observed in AP could reflect their neritic foraging 
behavior in waters above the Antarctic shelf. Finally, the high $\delta^{15} \mathrm{~N}$ values of AP could be explained by feeding in a food web supported in part by sea-ice phytoplankton, which has been shown to have elevated $\delta^{13} \mathrm{C}$ and $\delta^{15} \mathrm{~N}$ values (Hobson et al. 1995, Norkko et al. 2007).

The high $\delta^{15} \mathrm{~N}_{\text {phe }}$ values of Ks that forage in the polar front could be explained by the relative importance of mesopelagic prey in their diet (prey living around 300 to $500 \mathrm{~m}$ ). Previous studies have suggested there is a positive depth gradient in the $\delta^{15} \mathrm{~N}$ value of particulate nitrogen in the open ocean (Saino \& Hattori 1980, 1987, Dore et al. 2002, Trull et al. 2008). Saino \& Hattori (1980) found an overall increase of $9 \%$ in POM $\delta^{15} \mathrm{~N}$ values between 0 and $1000 \mathrm{~m}$ in the northeast Indian Ocean, and Trull et al. (2008) found $+0.5 \%$ enrichment in ${ }^{15} \mathrm{~N}$ with depth on Kerguelen Plateau up to $140 \mathrm{~m}$. If this nitrogen is incorporated and conserved in the food web, then prey that forage at depth (below 100 to $200 \mathrm{~m}$ ) can have higher $\delta^{15} \mathrm{~N}$ values than similar prey in the surface waters (Rau et al. 1989, Graham et al. 2007). Mintenbeck et al. (2007) showed a significant increase in the $\delta^{15} \mathrm{~N}$ values of benthic suspension feeders with water depth on the Weddell Sea shelf (up to $1000 \mathrm{~m}$ ). Thus, if predators forage on a greater proportion of mesopelagic prey, their $\delta^{15} \mathrm{~N}_{\text {phe }}$ values could potentially be higher than those of consumers feeding in the same region, but on a more epipelagic resource. KP make deep dives to forage, regularly exceeding $150 \mathrm{~m}$ depth (Kooyman et al. 1992), and feed almost exclusively on mesopelagic fish of the family Myctophidae, while other penguins (including AP, NRP, SRP) dive to shallower depths and mainly prey upon crustaceans (Cherel et al. 1993, 2007, Rodary et al. 2000, Tremblay \& Cherel 2003, Cherel 2008).

The $\delta^{15} \mathrm{~N}_{\text {phe }}$ values of SRP and NRP suggest that they do not forage in the same oceanic regions and that the difference in their bulk $\delta^{15} \mathrm{~N}$ values is due, in part, to baseline differences. These results also revealed that $\mathrm{KP}$ and AP have higher $\delta^{15} \mathrm{~N}_{\text {phe }}$ values than do rockhoppers, which could be explained by the foraging of $\mathrm{KP}$ on mesopelagic prey and of AP in the highly productive Antarctic shelf waters.

\section{Penguin $\delta^{15} \mathrm{~N}$ values and TLs (Hypothesis 2)}

Results of previous stomach content and bulk stable isotope analyses suggest that KPs have a higher TL than SRP and AP (Cherel et al. 2008). The compoundspecific isotope data support these observations, as the difference between the $\delta^{15} \mathrm{~N}$ values of trophic (glutamic acid) and source (phenylalanine) amino acids was greatest in KP (17.2\%; Table 3). If bulk isotope $\delta^{15} \mathrm{~N}$ values (Table 1) are interpreted only in the context of variations in trophic ecology, NRP $(9.2 \%)$ were at a lower TL than AP $(10.1 \%)$, and SRPs $(6.8 \%)$ were at the lowest TL. The AA $\delta^{15} \mathrm{~N}$ data, however, indicated that NRP had a higher $\Delta \delta^{15} \mathrm{~N}_{\text {glu-phe }}$ value, or TL, than both SRP (15.5 vs. $14.1 \%$ ) and AP (15.5 vs. $15.0 \%$ ). These conclusions are consistent with stomach content analyses, which indicate that NRP feed on squids and crustaceans, whereas SRP and AP forage mostly on crustaceans (Table 1). The bulk $\delta^{15} \mathrm{~N}$ difference $(2.4 \%$ ) between NRP and SRP is, therefore, not only due to a baseline difference, as discussed previously, but also to a difference in their TLs.

Our study thus suggests that the $\delta^{15} \mathrm{~N}$ analyses of individual AAs, such as glutamic acid and phenylalanine, can provide an opportunity to distinguish the relative influence of baseline variations and TL on the bulk $\delta^{15} \mathrm{~N}$ values of penguins. However, using Eq. (1) and a TEF of $7 \%$ (cf. McClelland \& Montoya 2002), the TL of penguin chicks ranged from 2.6 to 2.9 . A TL $<3$ is inconsistent with what we know about these penguins, as they are strictly carnivorous (Cherel et al. 1993, 2008). For example, the KP is a myctophid-eater, and myctophids forage mainly on meso- and macrozooplankton, including some herbivorous, omnivorous, and even carnivorous species. Consequently, a TL of KP cannot be $<4$. To match the expected TLs for penguins, and considering that the $4 \%$ phytoplankton $\Delta \delta^{15} \mathrm{~N}_{\text {glu-phe }}$ is correct, a TEF of $3.6 \%$ (see 'Results') has been used. Assuming this $\mathrm{TEF}_{\text {blood }}$ of $3.6 \%$ is correct for all penguin blood samples and $4 \%$ for the $\Delta \delta^{15} \mathrm{~N}_{\text {glu-phe }}$ value of phytoplankton, we estimate for the first time the TL for NRP chicks (4.2) and determine TLs for SRP, KP, and AP of 3.8, 4.6, and 4.0, respectively. Although our results suggest that the $7 \%$ TEF is inconsistent when $\Delta \delta^{15} \mathrm{~N}_{\text {glu-phe }}$ is used in penguin blood to determine $\mathrm{TL}$, uncertainty exists in the universal applicability of our lower TEF for samples of blood in organisms. The TEFs, particularly for tissues other than muscle, should be subjected to further experimental work conducted on a diverse assemblage of consumers.

The $\delta^{15} \mathrm{~N}$ values of glutamic acid and phenylalanine in penguin blood ( $\Delta \delta^{15} \mathrm{~N}_{\text {glu-phe }}$ ) allowed successful estimation of the relative TLs of the different species of penguins. However, before absolute TLs can be calculated, controlled experiments should be performed on seabirds and their diets to better constrain TEF for blood samples.

\section{Penguin $\delta^{13} \mathrm{C}$ values and foraging habitat (Hypothesis 3)}

Variations in bulk $\delta^{13} \mathrm{C}$ values have been interpreted as differences in the foraging habitats of the 4 penguin species and to spatial differences in the $\delta^{13} \mathrm{C}$ values at the base of the food web (Cherel \& Hobson 2007). Strong spatial gradients have been observed in the Southern Ocean, with a 9\% decrease in the $\delta^{13} \mathrm{C}$ val- 
ues of POM from low to high latitudes (François et al. 1993, Popp et al. 1999, Trull \& Armand 2001). The laboratory and field results of Fantle et al. (1999) showed that the essential AAs valine, leucine and phenylalanine did not exhibit significant ${ }^{13} \mathrm{C}$ enrichment from the diet and had lower $\delta^{13} \mathrm{C}$ values than the non-essential AAs. Based upon these observations we predicted that essential AAs would mirror the latitudinal bulk isotopic trends exhibited in Southern Ocean phytoplankton, i.e. the $\delta^{13} \mathrm{C}$ values of essential AAs in penguins that forage in lower latitude areas would be higher than those that forage at higher latitudes.

The $\delta^{13} \mathrm{C}$ values of 6 AAs (phenylalanine, lysine, arginine, glycine, proline, alanine) showed very good correlation with bulk $\delta^{13} \mathrm{C}$ values $\left(\mathrm{R}^{2}>0.8\right)$ and decreased with increasing latitude, suggesting that these AAs track $\delta^{13} \mathrm{C}$ baseline variations. In contrast to what has been found in blue crabs (Fantle et al. 1999), the $\delta^{13} \mathrm{C}$ values of essential AAs do not segregate relative to non-essential AAs in penguin's blood. Both essential AAs and non-essential AAs had higher $\delta^{13} \mathrm{C}$ values than bulk $\delta^{13} \mathrm{C}$ values. Interestingly, all essential AAs exhibited lower slopes relative to bulk $\delta^{13} \mathrm{C}$ values, indicating that the range of variation in these AA-specific $\delta^{13} \mathrm{C}$ values was lower relative to bulk $\delta^{13} \mathrm{C}$ values, while non-essential AAs (except for aspartic acid) had higher ranges. We are unable to interpret this pattern with our current understanding of carbon isotope fractionation of specific AAs in seabirds. As such, applying carbon CSIA to determine the foraging ecology and location of marine consumers is not straightforward, and may not even be applicable. Without baseline or prey $\delta^{13} \mathrm{C}$ data, it is not possible to determine whether some essential AAs fractionate or not relative to their diet. In an experimental study conducted on fish, McCullagh et al. (2008) also found that there was no clear pattern in ${ }^{13} \mathrm{C}$ fractionation relative to the essentiality of AAs. Instead, these authors found that phenylalanine alone showed no isotopic difference between the $\delta^{13} \mathrm{C}$ value of the consumer and its diet. In our study, phenylalanine had $\delta^{13} \mathrm{C}$ values close to the bulk values for all penguin species, which suggests that it may be the most appropriate AA for tracking changes in the baseline $\delta^{13} \mathrm{C}$ values and determining a marine consumer's foraging habitat. If one specific AA has to be chosen for simultaneous $\mathrm{C}$ and $\mathrm{N}$ isotope analysis, we propose phenylalanine, which has the closest values relative to bulk and is also a source AA for nitrogen.

\section{Conclusions}

Few studies have been conducted on carbon and nitrogen isotope analyses of individual AAs, and none of them examined seabirds. The present study shows for the first time that the $\delta^{15} \mathrm{~N}$ values of individual AAs, such as glutamic acid as a trophic AA and phenylalanine as a source AA, reflect the TL and the foraging regions of penguins. These results further support the use of compound-specific $\delta^{15} \mathrm{~N}$ isotope analysis to determine the foraging areas and TLs of marine consumers, from primary consumers to top predators. Previous analyses, however, focused on muscle and whole body, while the present study examined blood. Our results suggest that blood can be used to estimate relative TLs, but that the TEF reported in previous studies (i.e. $7 \%$ ) might not be appropriate to calculate absolute TL in penguin blood and, perhaps, in general, for seabirds. Controlled experiments are therefore needed to better constrain the TEF value for penguin blood. The $\delta^{13} \mathrm{C}$ values of 6 individual AAs followed the $\delta^{13} \mathrm{C}$ isotopic baseline, but without additional CSIA data on the diet or base of the food web, we were unable to further interpret the $\delta^{13} \mathrm{C}$ values of specific AAs isolated from penguin blood. Our study, however, suggests that glutamic acid $\left(\delta^{15} \mathrm{~N}\right)$ and phenylalanine (for both $\delta^{15} \mathrm{~N}$ and $\delta^{13} \mathrm{C}$ ) could be key individual AAs in the study of foraging habitat and the behavior of marine consumers.

Acknowledgements. We thank T. Rust and C. Hannides for their help with $\delta^{15} \mathrm{~N}$ analyses, and J. Middelburg and B. Veuger for making the $\delta^{13} \mathrm{C}$ analyses of the penguin blood samples possible. We also thank S. Sokolov for providing Indian Ocean front positions and chlorophyll a data for Fig. 1, and M. Patriat and P. Lopez for map and figure processing. This work was supported financially by the Program REMIGE-ANR Biodiversité 2005-011 and, for carbon analyses, partially by the Netherlands Organisation for Scientific Research.

\section{LITERATURE CITED}

Altabet MA (2001) Nitrogen isotopic evidence for micronutrient control of fractional $\mathrm{NO}_{3}^{-}$utilization in the equatorial Pacific. Limnol Oceanogr 46:368-380

> Altabet MA, François R (1994) Sedimentary nitrogen isotopic ratio as a recorder for surface ocean nitrate utilization. Global Biogeochem Cycles 8:103-116

Best PB, Schell DM (1996) Stable isotopes in southern right whale (Eubalaena australis) baleen as indicators of seasonal movements, feeding and growth. Mar Biol 124: 483-494

Bost CA, Georges JY, Guinet C, Cherel Y and others (1997) Foraging habitat and food intake of satellite-tracked king penguins during the austral summer at Crozet Archipelago. Mar Ecol Prog Ser 150:21-33

$>$ Bugoni L, McGill RAR, Furness RW (2008) Effects of preservation methods on stable isotope signatures in bird tissues. Rapid Commun Mass Spectrom 22:2457-2462

> Burton RK, Koch PL (1999) Isotopic tracking of foraging and long-distance migration in northeastern Pacific pinnipeds. Oecologia 119:578-585

Charrassin JB, Bost CA (2001) Utilisation of oceanic habitat by king penguins over the annual cycle. Mar Ecol Prog Ser 221:285-297 
Cherel Y (2008) Isotopic niches of emperor and Adélie penguins in Adélie Land, Antarctica. Mar Biol 154:813-821

Cherel Y, Hobson KA (2007) Geographical variation in carbon stable isotope signatures of marine predators: a tool to investigate their foraging areas in the Southern Ocean. Mar Ecol Prog Ser 329:281-287

Cherel Y, Verdon C, Ridoux V (1993) Seasonal importance of oceanic myctophids in king penguin diet at Crozet Islands. Polar Biol 13:355-357

Cherel Y, Hobson KA, Hassani S (2005) Isotopic discrimination between food and blood and feathers of captive penguins: implications for dietary studies in the wild. Physiol Biochem Zool 78:106-115

Cherel Y, Phillips RA, Hobson KA, McGill R (2006) Stable isotope evidence of diverse species-specific and individual wintering strategies in seabirds. Biol Lett 2:301-303

Cherel Y, Hobson KA, Guinet C, Vanpé C (2007) Stable isotopes document seasonal changes in trophic niches and winter foraging individual specialisation in diving predators from the Southern Ocean. J Anim Ecol 76:826-836

Cherel Y, Ducatez S, Fontaine C, Richard P, Guinet C (2008) Stable isotopes reveal the trophic position and mesopelagic fish diet of female southern elephant seals breeding on the Kerguelen Islands. Mar Ecol Prog Ser 370: 239-247

Chikaraishi Y, Kashiyama Y, Ogawa NO, Kitazato $\mathrm{H}$, Ohkouchi N (2007) Metabolic control of nitrogen isotope composition of amino acids in macroalgae and gastropods: implications for aquatic food web studies. Mar Ecol Prog Ser 342:85-90

Coplen TB, Brand WA, Gehre M, Gröning M, Meijer HAJ, Toman B, Verkouteren RM (2006) New guidelines for $\delta^{13} \mathrm{C}$ measurements. Anal Chem 78:2439-2441

Dore JE, Brum JR, Tupas LM, Karl DM (2002) Seasonal and interannual variability in sources of nitrogen supporting export in the oligotrophic subtropical North Pacific Ocean. Limnol Oceanogr 47:1595-1607

Fantle MS, Dittel AI, Schwalm SM, Epifanio CE, Fogel ML (1999) A food web analysis of the juvenile blue crab, Callinectes sapidus, using stable isotopes in whole animals and individual amino acids. Oecologia 120:416-426

François R, Altabet MA, Goericke R (1993) Changes in the $\delta^{13} \mathrm{C}$ of surface water particulate matter across the Subtropical Convergence in the SW Indian Ocean. Global Biogeochem Cycles 7:627-644

> Gibson JAE, Trull TW, Nichols PD, Summons RE, McMinn A (1999) Sedimentation of ${ }^{13} \mathrm{C}$-rich organic matter from Antarctic sea-ice algae: a potential indicator of past seaice extent. Geology 27:331-334

Goericke R, Fry B (1994) Variations of marine plankton $\delta^{13} \mathrm{C}$ with latitude, temperature, and dissolved $\mathrm{CO}_{2}$ in the world ocean. Global Biogeochem Cycles 8:85-90

Gouretski VV, Koltermann KP (2004) WOCE global hydrographic climatology. A technical report, 35, Berichte des BSH. Bundesamt für Seeschifffahrt und Hydrographie, Hamburg

- Graham BS, Grubbs D, Holland K, Popp BN (2007) A rapid ontogenetic shift in the diet of juvenile yellowfin tuna from Hawaii. Mar Biol 150:647-658

Hannides CCS, Popp BN, Landry MR, Graham BS (2009) Quantification of zooplankton trophic position in the North Pacific Subtropical Gyre using stable nitrogen isotopes. Limnol Oceanogr 54:50-61

- Hobson KA, Ambrose WG Jr, Renaud PE (1995) Sources of primary production, benthic-pelagic coupling, and trophic relationships within the Northeast Water Polynya: insights from $\delta^{13} \mathrm{C}$ and $\delta^{15} \mathrm{~N}$ analysis. Mar Ecol Prog Ser 128:1-10
Hobson KA, Gibbs HL, Gloutney ML (1997) Preservation of blood and tissue samples for stable carbon and stable nitrogen isotope analysis. Can J Zool 75:1720-1723

> Hyslop EJ (1980) Stomach content analysis. A review of methods and their application. J Fish Biol 17:411-429

> Iverson SJ, Field C, Bowen WD, Blanchard W (2004) Quantitative fatty acid signature analysis: a new method of estimating predator diets. Ecol Monogr 74:211-235

Jennings S, Warr KJ (2003) Environmental correlates of largescale spatial variation in the $\delta^{15} \mathrm{~N}$ of marine animals. Mar Biol 142:1131-1140

Karsh KL, Trull TW, Lourey MJ, Sigman DM (2003) Relationship of nitrogen isotope fractionation to phytoplankton size and iron availability during the Southern Ocean Iron RElease Experiment (SOIREE). Limnol Oceanogr 48: 1058-1068

Kooyman GL, Cherel Y, Le Maho Y, Croxall JP, Thorson PH, Ridoux V, Kooyman CA (1992) Diving behavior and energetics during foraging cycles in king penguins. Ecol Monogr 62:143-163

Krummen M, Hilkert AW, Juchelka D, Duhr A, Schluter HJ, Pesch R (2004) A new concept for isotope ratio monitoring liquid chromatography/mass spectrometry. Rapid Commun Mass Spectrom 18:2260-2266

> Lee SH, Schell DM, McDonald TL, Richardson WJ (2005) Regional and seasonal feeding by bowhead whales Balaena mysticetus as indicated by stable isotope ratios. Mar Ecol Prog Ser 285:271-285

> Lourey MJ, Trull TW, Sigman DM (2003) Sensitivity of $\delta^{15} \mathrm{~N}$ of nitrate, surface suspended and deep sinking particulate nitrogen to seasonal nitrate depletion in the Southern Ocean. Global Biogeochem Cycles 17:1081 doi: 10.1029/ 2002GB001973

McClelland JW, Montoya JP (2002) Trophic relationships and the nitrogen isotopic composition of amino acids in plankton. Ecology 83:2173-2180

- McClelland JW, Holl CM, Montoya JP (2003) Relating low $\delta^{15} \mathrm{~N}$ values of zooplankton to $\mathrm{N}_{2}$ fixation in the tropical North Atlantic: insights provided by stable isotope ratios of amino acids. Deep Sea Res I 50:849-861

> McCullagh JSO, Juchelka D, Hedges REM (2006) Analysis of amino acid ${ }^{13} \mathrm{C}$ abundance from human and faunal bone collagen using liquid chromatography isotope ratio mass spectrometry. Rapid Commun Mass Spectrom 20: 2761-2768

> McCullagh J, Gaye-Siessegger J, Focken U (2008) Determination of underivatized amino acid $\delta^{13} \mathrm{C}$ by liquid chromatography/isotope ratio mass spectrometry for nutritional studies: the effect of dietary non-essential amino acid profile on the isotopic signature of individual amino acids in fish. Rapid Commun Mass Spectrom 22: $1817-1822$

Ménard F, Lorrain A, Potier M, Marsac F (2007) Isotopic evidence of distinct feeding ecologies and movement patterns in two migratory predators (yellowfin tuna and swordfish) of the western Indian Ocean. Mar Biol 153: 141-152

Metges CC, Petzke K, Hennig U (1996) Gas chromatography/ combustion/isotope ratio mass spectrometric comparison of $\mathrm{N}$-acetyl- and N-pivaloyl amino acid esters to measure ${ }^{15} \mathrm{~N}$ isotopic abundances in physiological samples: a pilot study on amino acid synthesis in the upper gastrointestinal tract of minipigs. J Mass Spectrom 31:367-376

Michener RH, Schell DM (1994) Stable isotope ratios as tracers in marine aquatic food webs. In: Lajtha $\mathrm{K}$, Michener RH (eds) Stable isotopes in ecology and environmental sciences. Blackwell Scientific Publications, Oxford, p 138-157 
Mintenbeck K, Jacob U, Knust R, Arntz WE, Brey T (2007) Depth-dependence in stable isotope ratio $\delta^{15} \mathrm{~N}$ of benthic POM consumers: the role of particle dynamics and organism trophic guild. Deep Sea Res I 54:1015-1023

Newsome SD, Martinez del Rio C, Bearhop S, Phillips DL (2007) A niche for isotopic ecology. Front Ecol Environ 5: $429-436$

Norkko A, Trish SF, Cummings VJ, Gibbs MM, Andrew NL, Norkko J, Schwarz AM (2007) Trophic structure of coastal Antarctic food webs associated with changes in sea ice and food supply. Ecology 88:2810-2820

O'Brien DM, Boggs CL, Fogel ML (2005) The amino acids used in reproduction by butterflies: a comparative study of dietary sources using compound specific stable isotope analysis. Physiol Biochem Zool 78:819-827

Pinheiro JC, Bates DM (2000) Mixed-effects models in S and S-PLUS. Springer, New York

Popp BN, Trull T, Kenig F, Wakeham SG and others (1999) Controls on the carbon isotopic compositions of Southern Ocean phytoplankton. Global Biogeochem Cycles 13: 827-844

Popp BN, Graham BS, Olson RJ, Hannides CCS and others (2007) Insight into the trophic ecology of yellowfin tuna, Thunnus albacares, from compound-specific nitrogen isotope analysis of proteinaceous amino acids. In: Dawson T, Siegwolf R (eds) Stable isotopes as indicators of ecological change. Elsevier, Amsterdam, p 173-190

Quillfeldt P, McGill RAR, Furness RW (2005) Diet and foraging areas of Southern Ocean seabirds and their prey inferred from stable isotopes: review and case study of Wilson's storm-petrel. Mar Ecol Prog Ser 295:295-304

Rau GH, Heyraud M, Cherry RD (1989) ${ }^{15} \mathrm{~N} /{ }^{14} \mathrm{~N}$ and ${ }^{13} \mathrm{C} /{ }^{12} \mathrm{C}$ in mesopelagic shrimp from the northeast Atlantic Ocean: evidence for differences in diet. Deep-Sea Res 36: 1103-1110

Rodary D, Wienecke BC, Bost CA (2000) Diving behaviour of Adélie penguins (Pygoscelis adeliae) at Dumont D'Urville, Antarctica: nocturnal patterns of diving and rapid adaptations to changes in sea-ice condition. Polar Biol 23: $113-120$

Saino T, Hattori A (1980) ${ }^{15} \mathrm{~N}$ natural abundance in oceanic suspended particulate matter. Nature 283:752-754

Saino T, Hattori A (1987) Geographical variation of the water column distribution of suspended particulate organic nitrogen and its ${ }^{15} \mathrm{~N}$ natural abundance in the Pacific and its marginal seas. Deep-Sea Res 34:807-827

Schmidt K, Atkinson A, Stübing D, McClelland JW, Montoya JP, Voss M (2003) Trophic relationships among Southern Ocean copepods and krill: some uses and limitations of a stable isotope approach. Limnol Oceanogr 48:277-289

Editorial responsibility: Jacob González-Solís,

Barcelona, Spain
Schmidt K, McClelland JW, Mente E, Montoya JP, Atkinson A, Voss M (2004) Trophic-level interpretation based on $\delta^{15} \mathrm{~N}$ values: implications of tissue-specific fractionation and amino acid composition. Mar Ecol Prog Ser 266:43-58

Sears J, Hatch SA, O'Brien DM (2009) Disentangling effects of growth and nutritional status on seabird stable isotope ratios. Oecologia 159:41-48

Sigman DM, Casciotti KL (2001) Nitrogen isotopes in the ocean. In: Steele JH, Thorpe SA, Turekian KK (eds) Encyclopedia of ocean sciences: 1884-1894. Academic Press, New York

Sokolov S, Rintoul SR (2002) Structure of Southern Ocean fronts at $140^{\circ} \mathrm{E}$. J Mar Syst 37:151-184

> Sokolov S, Rintoul SR (2007) On the relationship between fronts of the Antarctic Circumpolar Current and surface chlorophyll concentrations in the Southern Ocean. J Geophys Res 112:C07030 doi: 10.1029/2006JC004072

Sokolov S, Rintoul SR (in press) The circulation structure and distribution of the Antarctic Circumpolar Current fronts. Part 1: mean circumpolar paths. J Geophys Res

Tamelander T, Kivimä C, Bellerby RGJ, Renaud PE, Kristiansen S (2009) Base-line variations in stable isotope values in an Arctic marine ecosystem: effects of carbon and nitrogen uptake by phytoplankton. Hydrobiologia 630:63-73

Tremblay Y, Cherel Y (2003) Geographic variation in the foraging behavior, diet and chick growth of rockhopper penguins. Mar Ecol Prog Ser 251:279-297

Trull TW, Armand L (2001) Insights into Southern Ocean carbon export from the $\delta^{13} \mathrm{C}$ of particles and dissolved inorganic carbon during the SOIREE iron release experiment. Deep Sea Res II 48:2655-2680

Trull TW, Daviesa D, Cascottie K (2008) Insights into nutrient assimilation and export in naturally iron-fertilized waters of the Southern Ocean from nitrogen, carbon and oxygen isotopes. Deep Sea Res II 55:220-240

Ueda K, Morgan SL, Fox A, Gilbart J, Sonesson A, Larsson L, Odham G (1989) D-Alanine as a chemical marker for the determination of streptococcal cell wall levels in mammalian tissues by gas chromatography/negative ion chemical ionisation mass spectrometry. Anal Chem 61: 265-270

- Wallace B, Seminoff J, Kilham S, Spotila J, Dutton P (2006) Leatherback turtles as oceanographic indicators: stable isotope analyses reveal a trophic dichotomy between ocean basins. Mar Biol 149:953-960

Wienecke BC, Lawless R, Rodary D, Bost CA and others (2000) Adélie penguin foraging behaviour and krill abundance along the Wilkes and Adélie Land coasts, Antarctica. Deep Sea Res II 47:2573-2587

Submitted: March 2, 2009; Accepted: July 10, 2009 Proofs received from author(s): September 17, 2009 